\title{
Asteraceae in the northern Espinhaço Range, Brazil: richness, endemism and conservation
}

\section{Mariana Guerra Staudt ${ }^{*}$, Maria Alves ${ }^{1}$ and Nádia Roque ${ }^{1,2}$}

Received: May 2, 2017

Accepted: July 10, 2017

\begin{abstract}
Floristic inventories focussing on the Espinhaço Range have revealed an extensive diversity for Asteraceae and emphasize the high degree of endemism of its species. This study aims to explore the species-rich Asteraceae through a floristic survey, and by identifying endemic records for the municipality of Morro do Chapéu, Bahia. Samples were collected during six field trips in different phytophysiognomies and approximately 1,400 exsiccatae from the main herbaria collections were examined. Asteraceae in Morro do Chapéu is represented by 18 tribes, 72 genera and 119 species. Eupatorieae and Vernonieae are the most species rich tribes and currently comprise 30 and 28 species, respectively, representing $50 \%$ of the local Asteraceae flora. Baccharis represents the richest genus with seven species, followed by Lepidaploa and Mikania with six species each. Species belonging to Eupatorieae, namely Acritopappus santosii, Acritopappus sp. nov., Lapidia apicifolia, Stylotrichium edmundoi, Scherya bahiensis, Trichogonia tombadorensis and, additionally, a new species of Vernonieae, Stilpnopappus sp. nov., are endemic to the municipality. We provide a checklist and identification key for the species, and report the occurrence of endemism and their importance for the biological conservation.
\end{abstract}

Keywords: Campos rupestres, Chapada Diamantina, Compositae, Espinhaço Range, floristic survey

\section{Introduction}

Asteraceae is considered the most species-rich angiosperm family with approximately 24,700 species distributed among 1,600-1,700 genera (Funk et al. 2009). It exhibits a wide range of evolutionary strategies and different life forms (herbs, shrubs, subshrubs, trees and lianas), and has a cosmopolitan distribution, although most of its species occur in grassland vegetation in temperate and semi-arid climates of tropical and subtropical zones (Bremer 1994; Funk et al. 2009).

The family is recognized by a set of morphological characteristics that includes flowers arranged in a head, introrse anthers connate into a tube, secondary presentation of pollen and a 2-carpellate inferior ovary with a basal and erect ovule which develops in a cypsela usually possessing a pappus (Roque \& Bautista 2008; Funk et al. 2009). It is recognized as a monophyletic group, and molecular studies (Panero \& Funk 2008; Funk et al. 2009; Panero et al. 2014) have proposed a new classification that recognizes 13 subfamilies and 44 tribes.

Twenty-eight tribes of Asteraceae have been recorded in Brazil, represented by 287 genera and 2,086 species; 66 genera and 1,315 species are endemic and occur in all phytogeographic areas of the country (BFG 2015). The greatest diversity of Asteraceae is in areas of cerrado (savanna), campos rupestres

\footnotetext{
${ }^{1}$ Programa de Pós-Graduação em Botânica, Departamento de Ciências Biológicas, Universidade Estadual de Feira de Santana, Km 03, BR 116, 44031-460, Feira de Santana, BA, Brazil

${ }^{2}$ Instituto de Biologia, Universidade Federal da Bahia, Campus Universitário de Ondina, 40170-110, Salvador, BA, Brazil
}

* Corresponding author: marianastaudt@gmail.com 
(rocky fields), campos sulinos (southern grasslands), caatinga and restinga (sand dunes) (Hind \& Miranda 2008).

Floristic surveys carried out in the Espinhaço Range have shown high species richness for Asteraceae, but particularly for Eupatorieae and Vernonieae, the most speciose tribes, followed by Helianteae and Astereae (Harley \& Simmons 1986; Giulietti et al. 1987; Grandi et al. 1988; Pirani et al. 1994; Hind 1995; 2003; Guedes \& Orge 1998; Zappi et al. 2003; Hatschbach et al. 2006; Moura \& Roque 2014; Campos et al. 2016; Roque et al. 2016). These studies have confirmed that many species are common, yet have distributions restricted to the Espinhaço Range, whereas other species are micro-endemic to only one region, either in the state of Bahia or Minas Gerais (Giulietti et al. 1987; Giulietti \& Pirani 1988; Harley 1995).

Approximately 125 genera and 500 species of Asteraceae have been documented in the campos rupestres of Espinhaço Range, of which 10 genera and about 75 species are endemic to Chapada Diamantina in Bahia (Roque et al. 2016). Thus, the focus of the present study was to perform a floristic inventory of Asteraceae and identify endemic records for the municipality of Morro do Chapéu in Chapada Diamantina, Bahia, Brazil.

\section{Materials and methods}

Study area

The Espinhaço Range extends approximately 1,000 km southwards from Serra da Jacobina in northern Bahia to Serra de Ouro Branco in southern Minas Gerais (40 47'06"$45^{\circ} 21^{\prime} 47^{\prime \prime} \mathrm{W} 9^{\circ} 18^{\prime} \mathrm{S}-20^{\circ} 53^{\prime} 46^{\prime \prime} \mathrm{S}$ ), varying in width from 50 to $100 \mathrm{~km}$ and in elevation from 800 to $2033 \mathrm{~m}$ (Giulietti et al. 1987).

Several vegetation types associated with a series of elevational strata comprise the Espinhaço Range, which is considered the center of diversity for many groups of angiosperms and hosts about $15 \%$ of the vascular flora of Brazil (Rapini et al. 2008; Silveira et al. 2015). Some $30 \%$ of the plant species of the Espinhaço Range are endemic to the campos rupestres (Giulietti et al. 1987), a phytophysiognomy composed of herbs and shrubs growing in sandy and acidic soils between large rocky outcrops (Giulietti \& Pirani 1988; Harley 1995; Pirani et al. 2003).

Chapada Diamantina belongs to the northern region of the Espinhaço Range, and can be divided into different types of natural vegetation, including caatinga, forest, cerrado and campos rupestres, all of which are extremely biologically diverse (Harley 1995).

The municipality of Morro do Chapéu is located in Chapada Diamantina within the semi-arid region of Bahia, and is characterized by tabular reliefs ranging between $480 \mathrm{~m}$ and 1,293 $\mathrm{m}$ in elevation (Rocha \& Costa 1995).
The landscape reflects the climatic particularities within the so-called "Polígono das Secas" including mountainous formations with pronounced scarps, deep valleys and high plateaus (Barbosa 1995). Due to the spatial and temporal variation inherent in the pluviometric regime of the region, including its intensity, different vegetation formations can develop on the same type of soil. Furthermore, the region is characterized by structurally compartmentalized reliefs, which generate different mesoclimates in adjacent areas (Silva 1995).

Morro do Chapéu is classified as an area of high priority for preservation in the Chapada Diamantina due to the fact that it possesses a unique vegetation typology of the caatinga (Maury 2002). According to Queiroz et al. (2005), within the Parque Estadual de Morro do Chapéu, the "Cidade das Pedras" exhibits a set of distinctive features because it possesses caatinga that is characterized by a flattened relief with different quartzite-arenite outcrops and extensive dune fields, possibly resulting from the effect of strong winds.

Morro do Chapéu encompases three conservation units, the Parque Estadual de Morro do Chapéu, APA Vereda do Romão Gramacho/Gruta dos Brejões and Monumento Natural da Cachoeira do Ferro Doido, which aid in the protection of the region's environment (Rocha et al. 2005; Rocha \& Pedreira 2009).

\section{Floristic survey}

Six field expeditions were carried out between November of 2014 and March of 2016, to survey species of Asteraceae. Fieldwork was schedule taking into account the main seasonal and pluviometric variation in the region. The main herbaria storing floral material from Chapada Diamantina were visited, and included ALCB, CEPEC, HUEFS, HRB, RB, R, SP and SPF (acronyms according to Thiers 2017), and approximately 1,400 exsiccatae were analyzed.

The principal collection sites for species of Asteraceae, and a set of photographs showing the different landscapes of the municipality of Morro do Chapéu, are provided in Figure 1. The map provided here was generated with ArcMap (version 10). Terminology for forest phytophysiognomies is based on the classification system proposed by IBGE (2012), whereas that for campos rupestres followed Giulietti et al. (1987) and that of caatinga vegetation followed Rizzini (1997).

The collection strategy involved random walking around the main access road and secondary smaller trails. Collected material was geo-referenced and processed according to Peixoto \& Maia (2003). All material was deposited in the ALCB herbarium with duplicates being sent to HUEFS. Species identification was aided by specific literature, protologues, comparisons with dried material and virtual collections. 

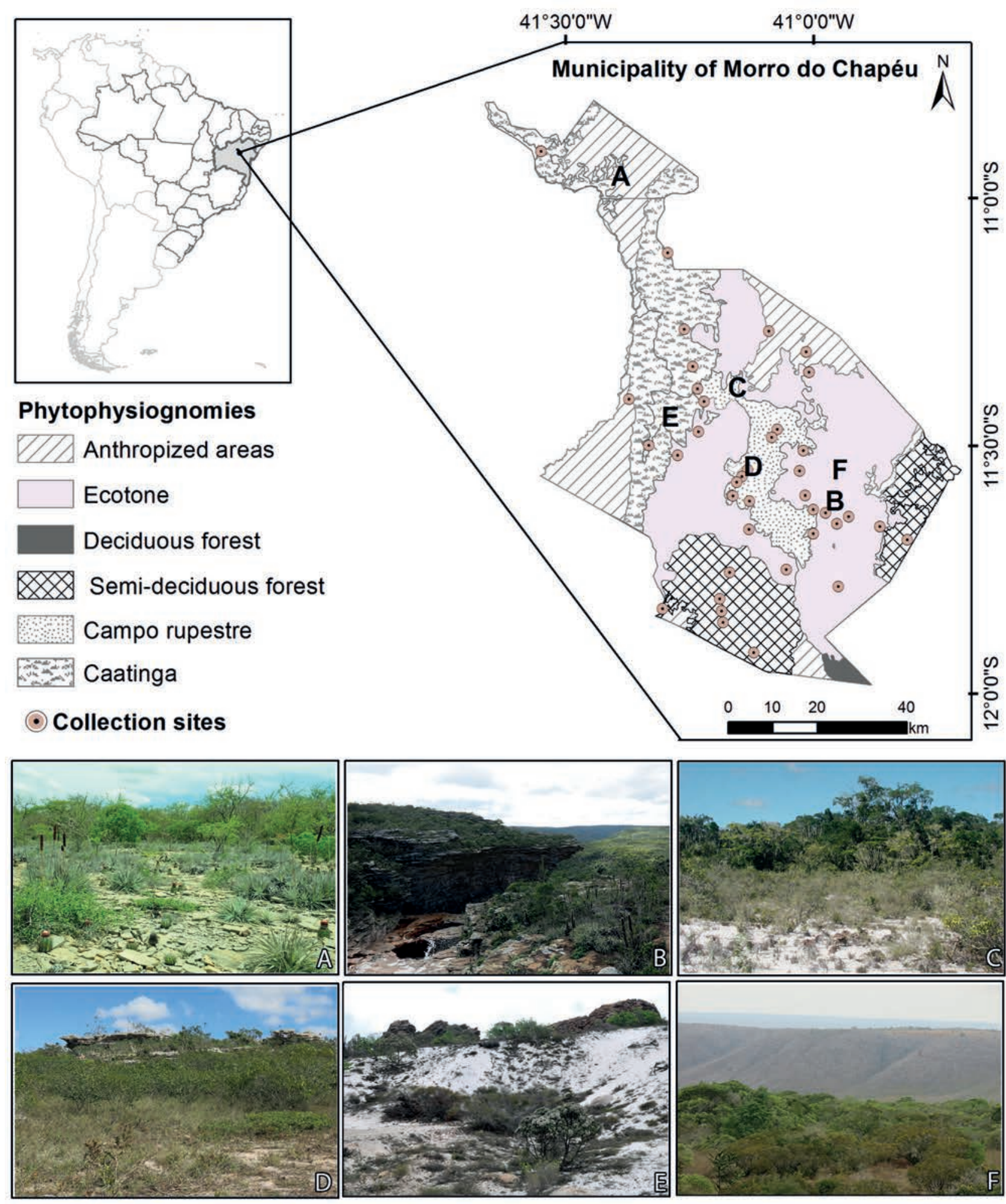

Figure 1. Map of the municipality of Morro do Chapéu with the main collection sites of the Asteraceae species and a set of pictures taken from the region's different landscapes: A - Gruta dos Brejões; B - Cachoeira do Ferro do Doido; C - Trilha da Guariba; D Tabuleiro do Tigre; E - Parque Estadual de Morro do Chapéu (Cidade das Pedras); F - Trilha da Veredinha (A-D. Cardoso; B, C, D, F-M. Staudt; E-L. Barres). 
Asteraceae of Morro do Chapéu, Bahia, Brazil: richness, endemism and conservation

Table 1. List of Asteraceae species from Morro do Chapéu, Bahia, Brazil; $\square$ Endemic species of Bahia; $\bullet$ Endemic species of Morro do Chapéu; Phytophysiognomies: CA-caatinga; CR- campo rupestre; SDF- semi-deciduous forest; Ecotone (CAC - caatinga and campo rupestre; $\mathrm{CEC}$ - cerrado and campo rupestre); $\mathrm{AA}$-anthropized area; Collection voucher.

\begin{tabular}{|c|c|c|}
\hline Tribe/species & Phytophysiognomies & Voucher \\
\hline \multicolumn{3}{|l|}{ Barnadesieae (1 genus/3 species) } \\
\hline Dasyphyllum brasiliense (Spreng.) Cabrera & SDF & E. Melo et al. 5035 \\
\hline - Dasyphyllum diamantinense Saavedra \& M. Monge & SDF & H.P. Bautista et. al 1061 \\
\hline Dasyphyllum sprengelianum (Gardner) Cabrera & $\mathrm{CA}$ & E. Melo et al. 4491 \\
\hline \multicolumn{3}{|l|}{ Mutisieae (1genus/1 species) } \\
\hline Chaptalia integerrima (Vell.) Burkart & CR/SDF/CEC/AA & M.G. Staudt et al. 35 \\
\hline \multicolumn{3}{|l|}{ Nassauvieae (1 genus/4 species) } \\
\hline Trixis antimenorrhoea (Schrank) Mart ex. Kuntze & $\mathrm{CA} / \mathrm{CR} / \mathrm{SDF} / \mathrm{AA}$ & M.G. Staudt et al. 30 \\
\hline Trixis calycina D. Don. & $\mathrm{CA} / \mathrm{CR}$ & M.G. Staudt et al. 81 \\
\hline - Trixis pruskii D.J.N. Hind & $\mathrm{CA} / \mathrm{SDF} / \mathrm{CEC}$ & E. Melo et al. 5509 \\
\hline Trixis vauthieri $\mathrm{DC}$. & $\mathrm{CA} / \mathrm{CR} / \mathrm{CEC}$ & M.G. Staudt et al. 94 \\
\hline \multicolumn{3}{|l|}{ Gochnatieae (2 genera/3 species) } \\
\hline Richterago discoidea (Less.) Kuntze & $\mathrm{CR}$ & M.L. Guedes et al. 10796 \\
\hline Moquiniastrum blanchetianum (DC.) G. Sancho & CAC & M.G. Staudt et al. 111 \\
\hline Moquiniastrum oligocephalum (Gardner) G. Sancho & CAC & M.G. Staudt et al. 142 \\
\hline \multicolumn{3}{|l|}{ Cichorieae (1 genus/1 species) } \\
\hline Sonchus oleraceus L. & $\mathrm{CR}$ & N. Hind et al. 3173 \\
\hline \multicolumn{3}{|l|}{ Vernonieae (13 genera/28 species) } \\
\hline Albertinia brasiliensis Spreng. & $\mathrm{CA}$ & E. Melo et al. 3185 \\
\hline Blanchetia heterotricha DC. & $\mathrm{CA} / \mathrm{SDF}$ & M.G. Staudt et al. 36 \\
\hline Centratherum punctatum Cass. & $\mathrm{CA} / \mathrm{CR} / \mathrm{SDF} / \mathrm{AA}$ & M.G. Staudt et al. 99 \\
\hline Chresta pacourinoides C.M. Siniscalchi \& B. Loeuille & $\mathrm{CA}$ & J.M. Gonçalves et al. 124 \\
\hline Cyrtocymura harleyi (H. Rob.) H. Rob. & CR & M.G. Staudt et al. 157 \\
\hline Cyrtocymura scorpioides (Lam.) H. Rob. & $\mathrm{CR} / \mathrm{SDF}$ & M.G. Staudt et al. 34 \\
\hline Elephantopus hirtiflorus DC. & $\mathrm{CR}$ & M.G. Staudt et al. 68 \\
\hline Elephantopus mollis Kunth & $\mathrm{CR} / \mathrm{SDF}$ & N. Hind et al. 3105 \\
\hline Eremanthus capitatus (Spreng.) MacLeish & $\mathrm{CR} / \mathrm{SDF} / \mathrm{CEC}$ & M.G. Staudt et al. 73 \\
\hline Eremanthus glomerulatus Less. & $\mathrm{CA} / \mathrm{CR}$ & M.G. Staudt et al. 79 \\
\hline Lepidaploa aurea (Mart. ex DC.) H. Rob. & $\mathrm{CA} / \mathrm{CR} / \mathrm{FES} / \mathrm{CEC}$ & M.G. Staudt et al. 147 \\
\hline - Lepidaploa bahiana H. Rob. & $\mathrm{CR}$ & M.G. Staudt et al. 78 \\
\hline Lepidaploa chalybaea (Mart. ex DC.) H. Rob. & $\mathrm{CA} / \mathrm{CR} / \mathrm{SDF}$ & M.G. Staudt et al. 84 \\
\hline Lepidaploa cotoneaster (Willd. ex Spreng.) H. Rob. & $\mathrm{CR} / \mathrm{CA} / \mathrm{SDF} / \mathrm{CEC}$ & M.G. Staudt et al. 105 \\
\hline Lepidaploa lilacina (Mart. ex DC.) H. Rob. & $\mathrm{CA} / \mathrm{CR} / \mathrm{CAC}$ & M.G. Staudt et al. 122 \\
\hline - Lepidaploa tombadorensis (H. Rob.) H. Rob. & $\mathrm{CA} / \mathrm{CR} / \mathrm{CAC}$ & M.G. Staudt et al. 91 \\
\hline Lessingianthus morii (H. Rob.) H. Rob. & $\mathrm{CR}$ & R.M. Harley 19242 \\
\hline - Paralychnophora harleyi (H. Rob.) D.J.N. Hind. & $\mathrm{CR}$ & G. Martinelli et al. 5318 \\
\hline Paralychnophora reflexoauriculata (G.M. Barroso) MacLeish & $\mathrm{CR} / \mathrm{SDF} / \mathrm{CEC}$ & M.G. Staudt et al. 71 \\
\hline Piptocarpha leprosa (Less.) Baker & CEC & E. Melo et al. 9612 \\
\hline - Stilpnopappus semirianus R. Esteves & $\mathrm{CR} / \mathrm{CEC}$ & M.G. Staudt et al. 62 \\
\hline Stilpnopappus suffruticosus Gardner & $\mathrm{CR}$ & M.G. Staudt et al. 109 \\
\hline - Stilpnopappus tomentosus Mart. ex DC. & $\mathrm{CR}$ & H.A. Ogasawara et al. 393 \\
\hline - Stilpnopappus sp. nov. & $\mathrm{CR}$ & M.G. Staudt et al. 03 \\
\hline Vernonanthura brasiliana (L.) H. Rob. & $\mathrm{CA} / \mathrm{SDF} / \mathrm{CAC}$ & M.G. Staudt et al. 98 \\
\hline Vernonanthura laxa (Gardner) H. Rob. & CEC & E.E. de Miranda 13 \\
\hline Vernonanthura polyanthes (Spreng.) A.J. Vega \& M. Dematt. & $\mathrm{CA} / \mathrm{SDF}$ & F. França et al. 5851 \\
\hline Vernonanthura subverticillata (Sch. Bip. ex Baker) H. Rob. & $\mathrm{CA} / \mathrm{CAC} / \mathrm{CEC}$ & E. Melo et al. 10020 \\
\hline \multicolumn{3}{|l|}{ Moquinieae (1 genus/1 species) } \\
\hline Moquinia racemosa (Spreng.) DC. & $\mathrm{CR} / \mathrm{CAC}$ & M.G. Staudt et al. 125 \\
\hline \multicolumn{3}{|l|}{ Gnaphalieae (2 genera/2 species) } \\
\hline Achyrocline satureioides (Lam.) DC. & $\mathrm{CR} / \mathrm{AA}$ & M.G. Staudt et al. 123 \\
\hline Gamochaeta americana (Mill.) Wedd. & CR/AA & J.L. Ferreira et al. 63 \\
\hline \multicolumn{3}{|l|}{ Astereae (3 genera/10 species) } \\
\hline - Baccharis alleluia A.S. Oliveira \& Deble & $\mathrm{CA}$ & J.P. Souza $s / n^{\circ}$ \\
\hline Baccharis calvescens DC. & CA/AA & R.M. Harley et al. 19395 \\
\hline
\end{tabular}


Table 1. Cont.

\begin{tabular}{|c|c|c|}
\hline Tribe/species & Phytophysiognomies & Voucher \\
\hline Baccharis cinerea DC. & $\mathrm{CA} / \mathrm{CR} / \mathrm{AA}$ & R.M. Harley et al. 3279 \\
\hline Baccharis linearifolia (Lam.) Pers. & $\mathrm{CR} / \mathrm{SDF}$ & R. Orlandini 272 \\
\hline Baccharis retusa DC. & SDF & E.B. Miranda et al. 100 \\
\hline Baccharis reticularia $\mathrm{DC}$. & $\mathrm{CR}$ & S.A. Mori et al. 14451 \\
\hline Baccharis trinervis Pers. & SDF & E. Melo et al. 11163 \\
\hline Conyza primulifolia (Lam.) Cuatrec. \& Lourteig & CR/AA & R.M. Harley et al. 19311 \\
\hline Conyza sumatrensis (Retz.) E. Walker & CR/AA & N. Hind et al. 3239 \\
\hline Egletes viscosa (L.) Less. & CA/AA & E. Melo et al. 11140 \\
\hline \multicolumn{3}{|l|}{ Anthemideae (1genus/1 species) } \\
\hline Artemisia vulgaris L. & $\mathrm{AA}$ & N.C.B. Silva 90 \\
\hline \multicolumn{3}{|l|}{ Inuleae ( 3 genera/3 species) } \\
\hline Epaltes brasiliensis DC. & CA & F. França et al. 6101 \\
\hline Pluchea sagittalis (Lam.) Cabrera & CA/AA & R.F. Machado 406 \\
\hline Pterocaulon alopecuroides (Lam.) DC. & SDF & J.M. Gonçalves et al. 39 \\
\hline \multicolumn{3}{|l|}{ Senecioneae (4 genera/4 species) } \\
\hline Emilia fosbergii Nicolson & $\mathrm{CR} / \mathrm{SDF} / \mathrm{AA}$ & M.G. Staudt et al. 75 \\
\hline Erechtites hieracifolius (L.) Raf. ex DC. & $\mathrm{AA}$ & H.P. Bautista 373 \\
\hline - Hoehnephytum almasense D.J.N. Hind & CR & H.S. Irwin et al. 32422 \\
\hline Senecio macrotis Baker & CA & E. Pereira 2144 \\
\hline \multicolumn{3}{|l|}{ Neurolaeneae (2 genera/2 species) } \\
\hline Enydra radicans (Willd.) Lack & CA/AA & F. França et al. 6077 \\
\hline Calea candolleana (Gardner) Baker & $\mathrm{CA} / \mathrm{CR} / \mathrm{CAC}$ & M.G. Staudt et al. 137 \\
\hline \multicolumn{3}{|l|}{ Heliantheae (15 genera/19 species) } \\
\hline Acmella ciliata (Kunth) Cass. & $\mathrm{CA} / \mathrm{SDF}$ & F.B. Silva et al. 36 \\
\hline Acmella uliginosa (Sw.) Cass. & $\mathrm{CA} / \mathrm{SDF}$ & M.G. Staudt et al. 101 \\
\hline Ambrosia artemisiifolia $\mathrm{L}$. & $\mathrm{AA}$ & E. Melo et al. 11144 \\
\hline Aspilia martii Baker & $\mathrm{CR}$ & M.G. Staudt et al. 110 \\
\hline Aspilia subalpestris Baker & SDF/CEC & A. Gandara et al. 83 \\
\hline Baltimora geminata (Brandegee) Stuessy & CA & E. Melo et al. 5662 \\
\hline Blainvillea acmella (L.) Philipson & $\mathrm{CR}$ & M. Alves et al. 137 \\
\hline Delilia biflora (L.) Kuntze & SDF & M.G. Staudt et al. 39 \\
\hline Eclipta prostrata (L.) L. & $\mathrm{AA}$ & E. Melo et al. 3153 \\
\hline Melanthera latifolia (Gardner) Cabrera & CR & Pe. Pereira et al. s/n ${ }^{\circ}$ \\
\hline Simsia dombeyana DC. & CA & E. Melo et al. 4739 \\
\hline Synedrellopsis grisebachii Hieron. \& Kuntze & CA & L.P. Queiroz et al. 13219 \\
\hline Tilesia baccata (L.) Pruski & CEC & E. Melo et al. 12117 \\
\hline Tithonia diversifolia (Hemsl.) A. Gray & $\mathrm{AA}$ & M. Alves et al. 140 \\
\hline Tithonia rotundifolia (Mill.) S.F. Blake & $\mathrm{AA}$ & M. Alves et al. 136 \\
\hline Verbesina glabrata Hook. \& Arn. & $\mathrm{CA} / \mathrm{CR}$ & E. Melo et al. 5072 \\
\hline Verbesina macrophylla (Cass.) S.F. Blake & $\mathrm{CR} / \mathrm{SDF} / \mathrm{CEC} / \mathrm{AA}$ & M.G. Staudt et al. 46 \\
\hline Wedelia goyazensis Gardner & CA & M.G. Staudt et al. 29 \\
\hline Zinnia elegans Jacq. & $\mathrm{AA}$ & M.G. Staudt et al. 40 \\
\hline \multicolumn{3}{|l|}{ Coreopsideae (1 genus/1 species) } \\
\hline Bidens pilosa $\mathrm{L}$. & CR/AA & N. Hind et al. 3242 \\
\hline \multicolumn{3}{|l|}{ Tageteae (2 genera/3 species) } \\
\hline Porophyllum obscurum (Spreng.) DC. & $\mathrm{CR}$ & H.P. Bautista et al. 2507 \\
\hline Porophyllum ruderale (Jacq.) Cass. & $\mathrm{CR}$ & M.L. Guedes et al.102251 \\
\hline Tagetes minuta L. & $\mathrm{CA} / \mathrm{CR} / \mathrm{AA}$ & M.G. Staudt et al. 13 \\
\hline \multicolumn{3}{|l|}{ Millerieae (2 genera/3 species) } \\
\hline Acanthospermum australe (Loefl.) Kuntze & $\mathrm{CR}$ & N. Hind et al. 3237 \\
\hline Acanthospermum hispidum DC. & CR/AA & N. Hind et al. 3091 \\
\hline Tridax procumbens $\mathrm{L}$. & SDF/AA & M.G. Staudt et al. 41 \\
\hline \multicolumn{3}{|l|}{ Eupatorieae (17 genera/30 species) } \\
\hline Acritopappus confertus (Gardner) R.M. King \& H. Rob. & $\mathrm{CA} / \mathrm{CR} / \mathrm{CAC} / \mathrm{CEC}$ & M.G. Staudt et al. 116 \\
\hline - Acritopappus heterolepis (Baker) R.M. King \& H. Rob. & SDF & M.G. Staudt et al. 126 \\
\hline - Acritopappus prunifolius R.M. King \& H. Rob. & CEC & R.M. Harley 22994 \\
\hline
\end{tabular}


Table 1. Cont.

\begin{tabular}{|c|c|c|}
\hline Tribe/species & Phytophysiognomies & Voucher \\
\hline - Acritopappus santosii R.M. King \& H. Rob. & $\mathrm{CA} / \mathrm{CR} / \mathrm{CAC} / \mathrm{CEC}$ & M.G. Staudt et al. 139 \\
\hline - Acritopappus sp. nov. & $\mathrm{CA} / \mathrm{SDF}$ & M.G. Staudt et al. 104 \\
\hline Ageratum conyzoides L. & CR/AA & M.G. Staudt et al. 100 \\
\hline - Agrianthus empetrifolius Mart. ex DC. & CR & E. Melo et al. 5068 \\
\hline Bahianthus viscosus (Spreng.) R.M. King \& H. Rob. & $\mathrm{CR}$ & H.P. Bautista 2948 \\
\hline Bejaranoa semistriata (Baker) R.M. King \& H. Rob. & $\mathrm{CA} / \mathrm{CR}$ & M.G. Staudt et al. 102 \\
\hline - Chromolaena morii R.M. King \& H. Rob. & CR & M.G. Staudt et al. 120 \\
\hline Chromolaena maximilianii (Schrad. ex DC.) R.M. King \& H. Rob. & $\mathrm{CR} / \mathrm{SDF}$ & M.G. Staudt et al. 33 \\
\hline Conocliniopsis prasiifolia (DC.) R.M. King \& H. Rob. & $\mathrm{CA} / \mathrm{CR}$ & M.G. Staudt et al. 72 \\
\hline Koanophyllon conglobatum (DC.) R.M. King \& H. Rob. & $\mathrm{CR}$ & R.P. Orlandini 460 \\
\hline - Lapidia apicifolia N. Roque \& S.C. Ferreira & CR & M.G. Staudt et al. 74 \\
\hline Mikania congesta DC. & $\mathrm{CR} / \mathrm{SDF} / \mathrm{AA}$ & E. Melo et al. 8460 \\
\hline Mikania cordifolia (L.f.) Willd. & CA & M.L. Guedes et al. 12985 \\
\hline Mikania elliptica DC. & $\mathrm{CR} / \mathrm{SDF}$ & M.G. Staudt et al. 95 \\
\hline Mikania glomerata Spreng. & SDF & M.L. Guedes et al. 10797 \\
\hline - Mikania grazielae R.M.King \& H.Rob. & SDF & A. Gandara et al. 137 \\
\hline Mikania phaeoclados Mart. & $\mathrm{CR} / \mathrm{SDF}$ & G. Hatschbach 39673 \\
\hline - Prolobus nitidulus (Baker) R.M. King \& H. Rob. & CR & M G. Staudt et al. 67 \\
\hline Pseudobrickellia brasiliensis (Spreng.) R.M. King \& H. Rob. & CR & M.L. Guedes et al. 16279 \\
\hline - Scherya bahiensis R.M. King \& H. Rob. & CR & M.G. Staudt et al. 130 \\
\hline Stevia morii R.M. King \& H. Rob. & CR & H.P. Bautista 405 \\
\hline - Stylotrichium corymbosum (DC.) Mattf. & CR & J.L. Ferreira et al. 43 \\
\hline - Stylotrichium edmundoi G.M. Barroso & CR & M.G. Staudt et al. 113 \\
\hline Symphyopappus decussatus Turcz. & SDF & A.A. Conceição et al. 2434 \\
\hline Trichogonia campestris Gardner & $\mathrm{CA} / \mathrm{CR} / \mathrm{AA}$ & M.G. Staudt et al. 150 \\
\hline Trichogonia salviifolia Gardner & $\mathrm{CA} / \mathrm{CR} / \mathrm{SDF} / \mathrm{AA}$ & M.G. Staudt et al. 129 \\
\hline - Trichogonia tombadorensis R.M. King \& H. Rob. & $\mathrm{CR}$ & M.G. Staudt et al. 149 \\
\hline
\end{tabular}

The presentation of the tribes follows Funk et al. (2009), starting with the Barnadesieae and finishing with the Eupatorieae. Within each tribe, genera and respective species are listed in alphabetic order (Tab.1, Figs. 2-8).

\section{Results and discussion}

\section{Asteraceae in Morro do Chapéu}

In Morro do Chapéu, Asteraceae is represented by 18 tribes, 72 genera and 119 species (Tab. 1). Corroborating previous floristic surveys in Espinhaço Range (Giulietti et al. 1987; Hind 1995; 2003; Zappi et al. 2003; Moura \& Roque 2014; Campos et al. 2016; Roque et al. 2016), Eupatorieae and Vernonieae were the most diverse tribes with 30 and 28 species respectively, and together comprise $50 \%$ of the local diversity of Asteraceae. Heliantheae was the third most diverse tribe with 19 species, representing about a third of Heliantheae species registered in the state of Bahia by Alves \& Roque (2016).

Baccharis was the richest genus with seven species, followed by Lepidaploa and Mikania, with six species each; results similar to those observed in other areas of Chapada
Diamantina (Harley 1995; Zappi et al. 2003; Moura \& Roque 2014; Roque et al. 2016). Other speciose genera included Acritopappus with five species; Stilpnopappus, Trixis, and Vernonanthura, with four species each; and Dasyphyllum and Trichogonia with three each. The remaining genera were represented by only one or two species each, and represented $60 \%$ of the species of Asteraceae in the area.

Seven genera found at Morro do Chapéu are monotypic (Albertinia, Bahianthus, Conocliniopsis, Lapidia, Prolobus, Scherya and Synedrellopsis), while 23 species are endemic to the state of Bahia, of which 19 belong to the tribes Eupatorieae and Vernonieae (Tab. 1).

Morro do Chapéu is the type locality for Acritopappus prunifolius, Cyrtocymura harleyi, Lepidaploa tombadorensis and Stilpnopappus semirianus. Moreover, Acritopappus santosii, Acritopappus sp. nov., Lapidia apicifolia, Stylotrichium edmundoi, Scherya bahiensis and Trichogonia tombadorensis, all belonging to the tribe Eupatorieae, and a new species, Stilpnopappus sp. nov. of to the tribe Vernonieae, are recorded as endemic to the municipality (Tab. 1).

Stilpnopappus suffruticosus is here recorded as a new record for the state of Bahia, and is classified as endangered in the Red Book (Martinelli \& Moraes 2013), even as Paralychnophora harleyi, Stilpnopappus semirianus, Stylotrichium corymbosum and Stylotrichium edmundoi. 

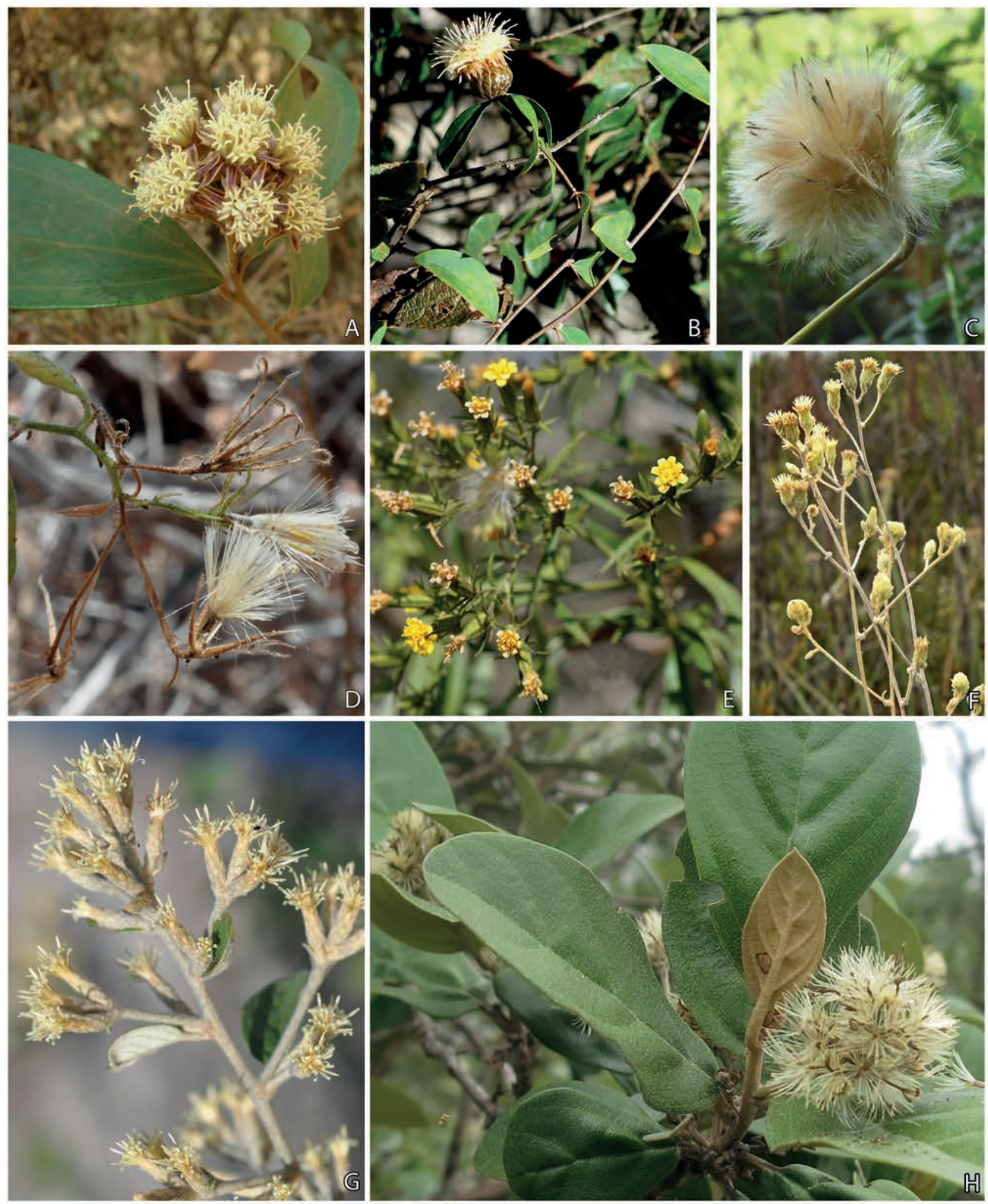

Figure 2. A - Dasyphyllum brasiliense; $\mathbf{B}$ - Dasyphyllum sprengelianum; C - Chaptalia integerrima; $\mathbf{D}$ - Trixis calycina; $\mathbf{E}$ - Trixis vauthieri; F-Richterago discoidea; G-Moquiniastrum blanchetianum; $\mathbf{H}$ - Moquiniastrum oligocephalum (A, B, H-N. Roque; C-A. Gandara; D, E, G-L. Barres; F-L. Moura). 

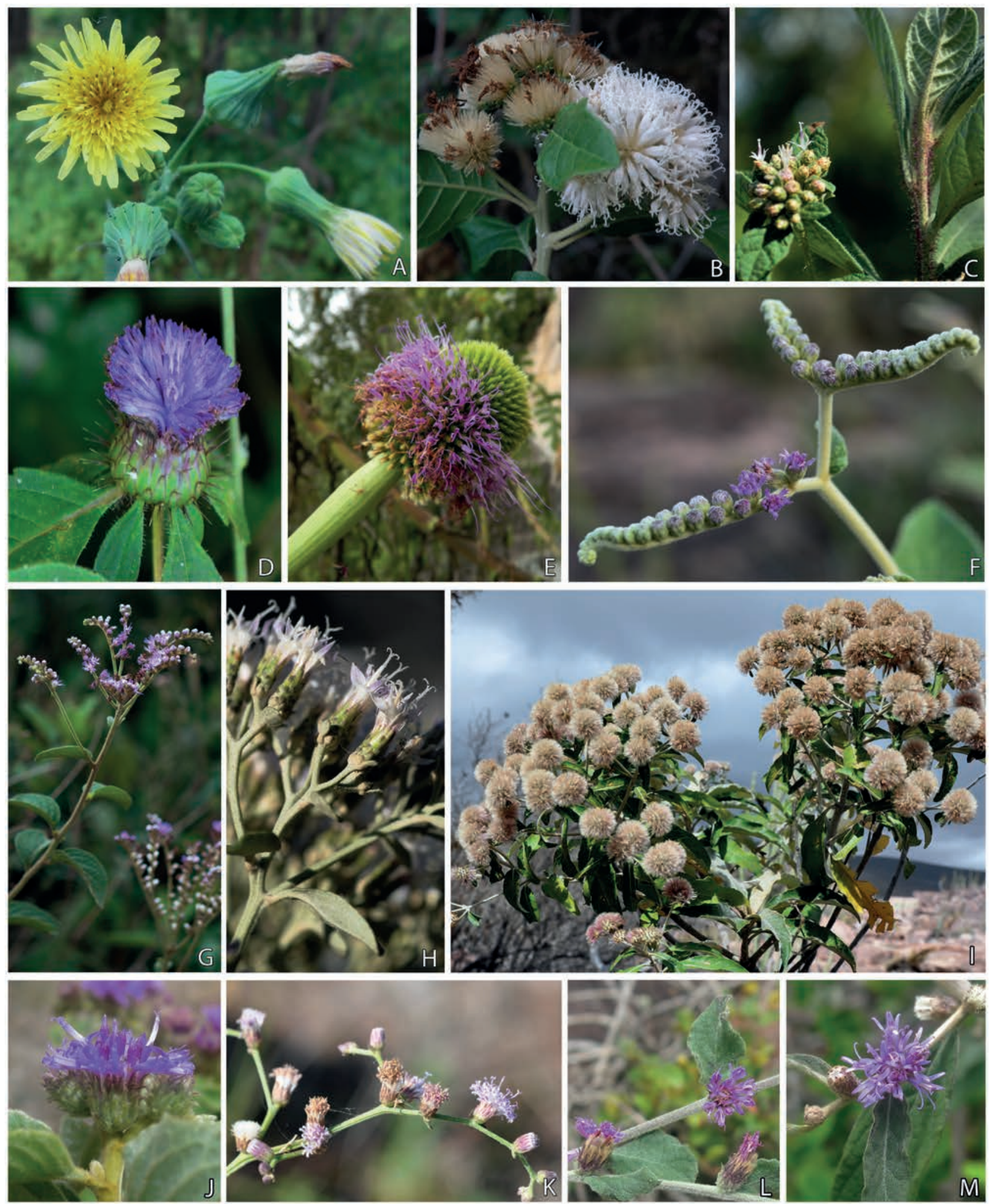

Figure 3. A - Sonchus oleraceus; B - Albertinia brasiliensis; C - Blanchetia heterotricha; D - Centratherum punctatum; E - Chresta pacourinoides; F - Cyrtocymura harleyi; G - Cyrtocymura scorpioides; $\mathbf{H}$ - Eremanthus capitatus; I - Eremanthus glomerulatus; J - Lepidaploa aurea; K-Lepidaploa bahiana; L - Lepidaploa chalybaea; $\mathbf{M}$ - Lepidaploa cotoneaster (A-V. Amorim; B-H. Ogasawara; C, D, F-A. Gandara; E-L. Campos; G - L. Pataro; H, K, I - L. Barres; J, L, M - M. Staudt). 

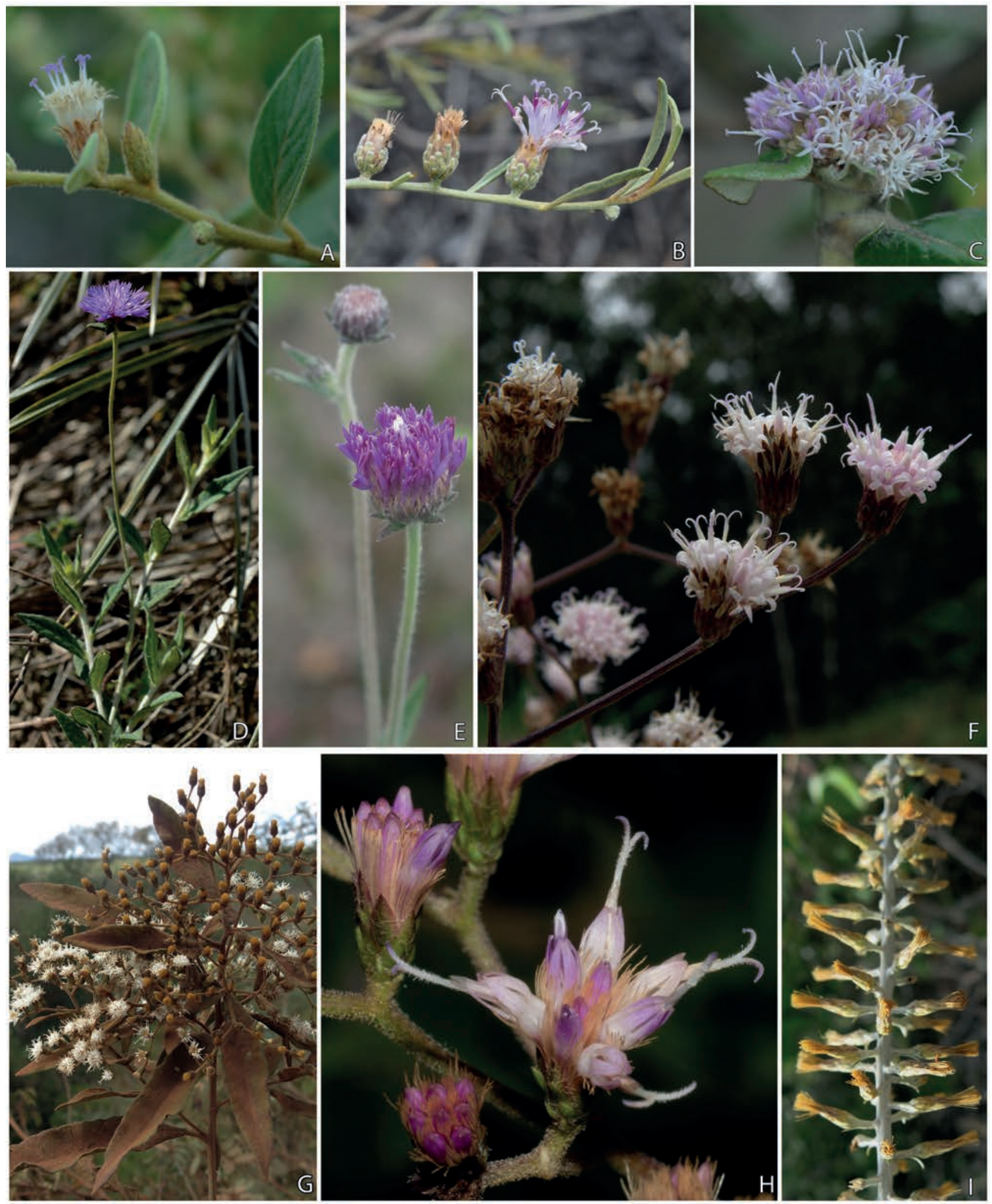

Figure 4. A - Lepidaploa lilacina; B - Lepidaploa tombadorensis; C - Paralychnophora reflexoauriculata; $\mathbf{D}$ - Stilpnopappus semirianus; E - Stilpnopappus sp. nov.; F - Vernonanthura brasiliana; G - Vernonanthura polyanthes; H - Vernonanthura subverticillata; I - Moquinia racemosa (A, D - A. Gandara; B, C - L. Barres; E - M. Staudt; F - H. Ogasawara; G- L. Moura; H - L. Pataro; I - M. Alves). 
Asteraceae of Morro do Chapéu, Bahia, Brazil: richness, endemism and conservation
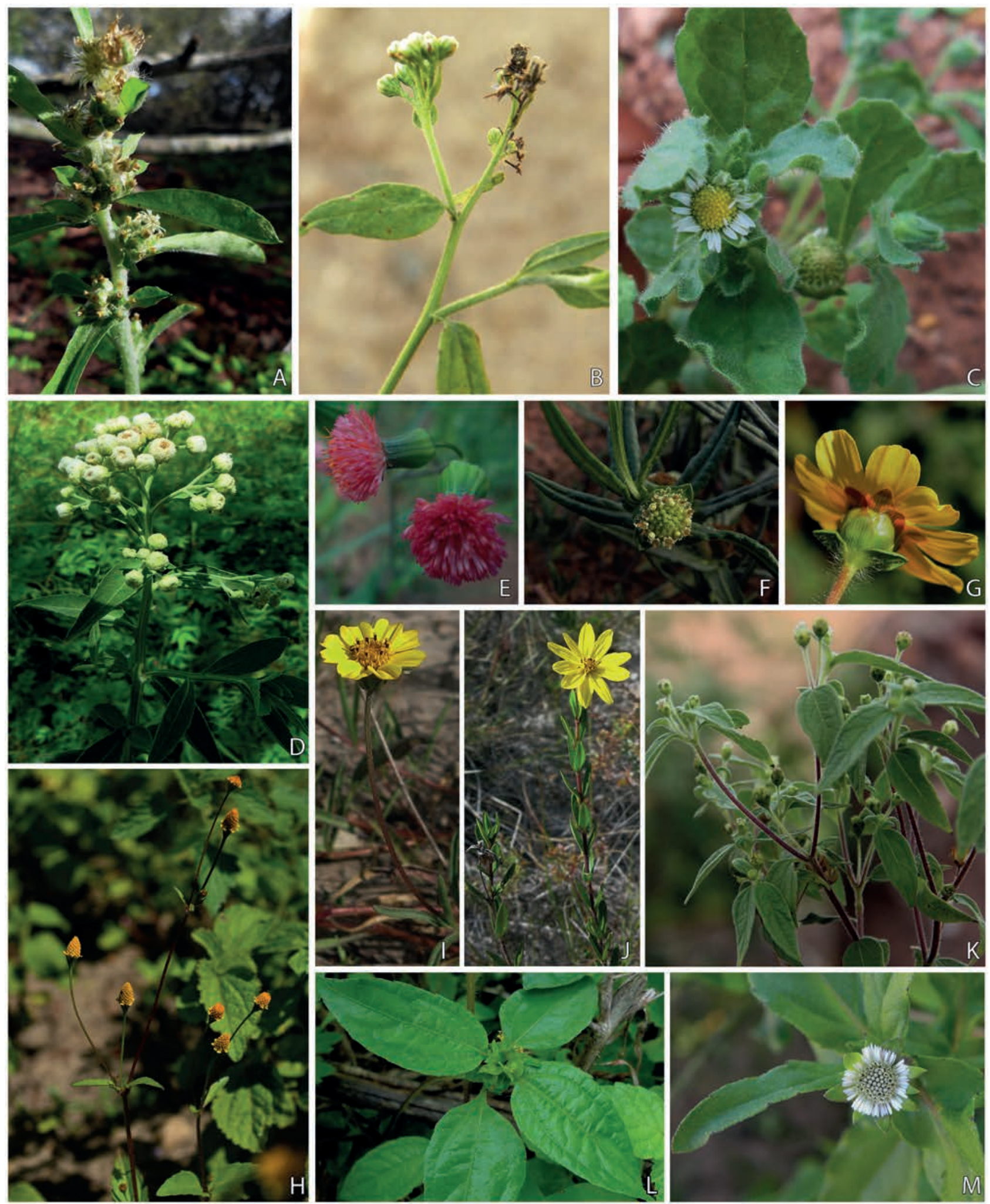

Figure 5. A - Gamochaeta americana; $\mathbf{B}$ - Baccharis cinerea; C - Egletes viscosa; D - Pluchea sagittalis; $\mathbf{E}$ - Emilia fosbergii; $\mathbf{F}$ - Enydra radicans; $\mathbf{G}$ - Calea candolleana; $\mathbf{H}$ - Acmella uliginosa; I - Aspilia martii; J - Aspilia subalpestris; $\mathbf{K}$ - Blainvillea acmella; $\mathbf{L}$ - Delilia biflora; M - Eclipta prostrata (A, C, D, E, F, L, M - V. Amorim; B, G, H - A. Gandara; I - M. Staudt; J - M. Alves; K - L. Moura). 

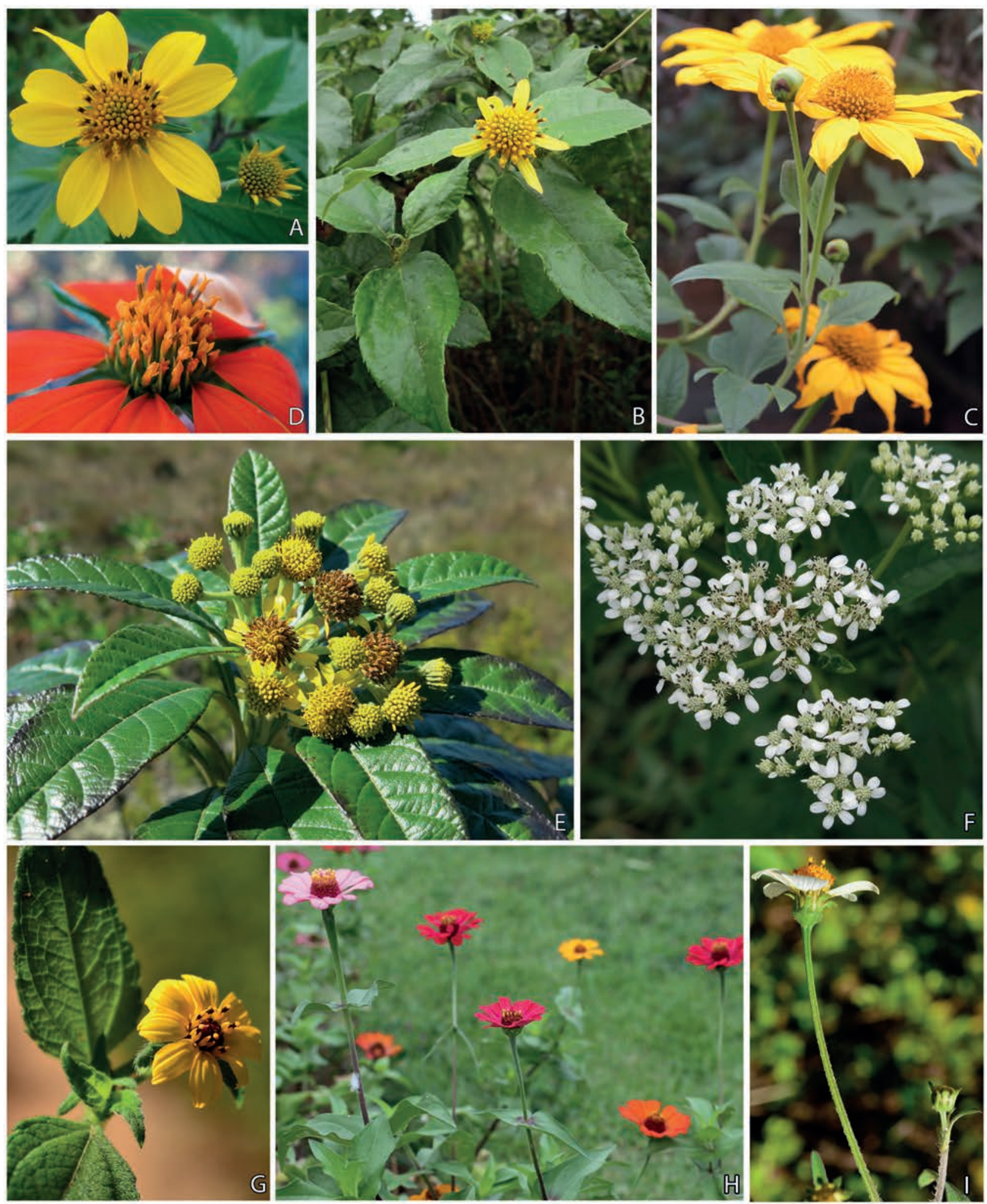

Figure 6. A - Melantheera latifolia; B - Tilesia baccata; C - Tithonia diversifolia; D - Tithonia rotundifolia; $\mathbf{E}$ - Verbesina glabrata; $\mathbf{F}$ Verbesina macrophylla; G - Wedelia goyazensis; H - Zinnia elegans; I - Bidens pilosa (A, B - V. Amorim; C, D, F, H - L. Moura; E - M. Alves; G, I - A. Gandara). 
Asteraceae of Morro do Chapéu, Bahia, Brazil:

richness, endemism and conservation
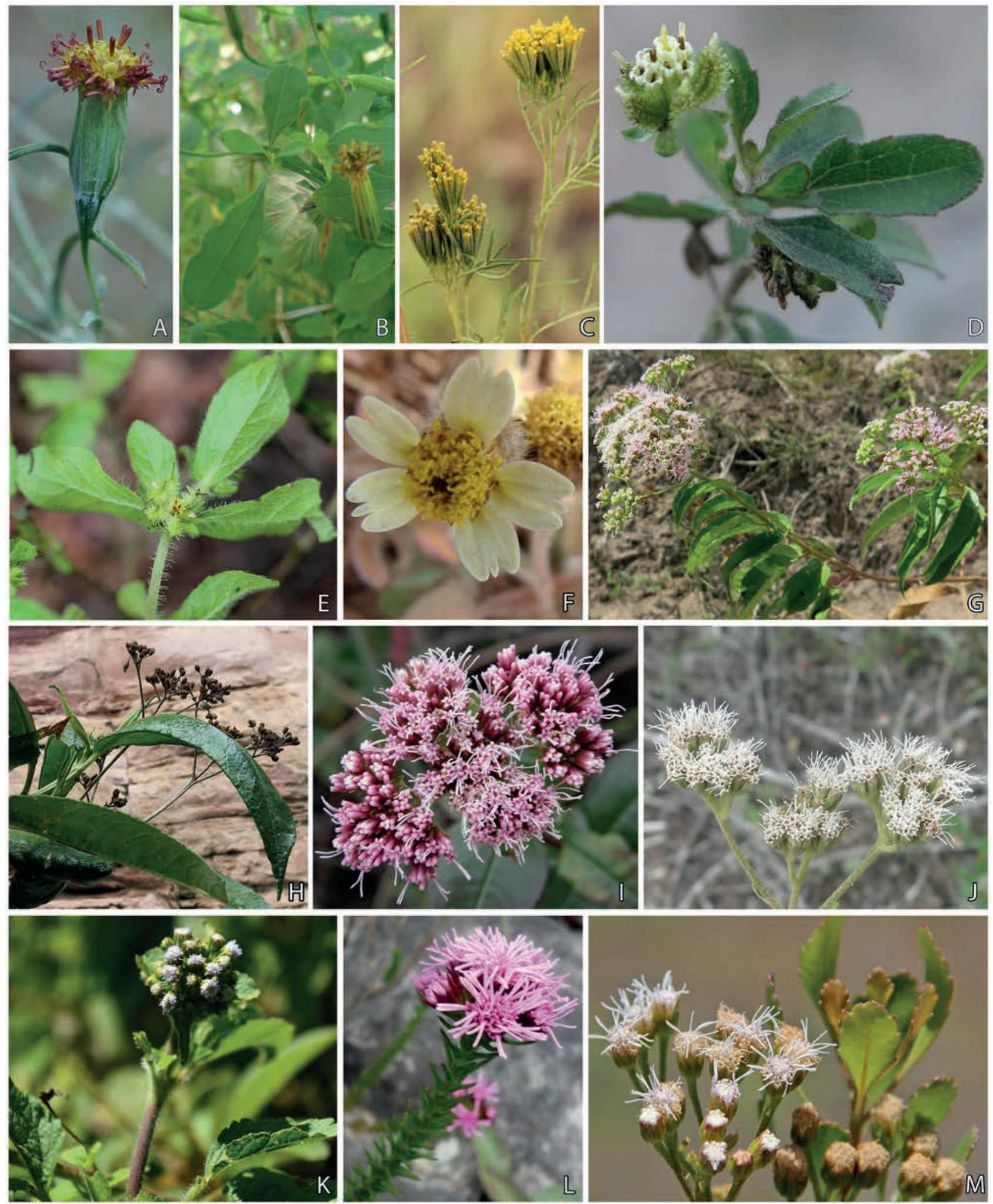

Figure 7. A - Porophyllum obscurum; B - Porophyllum ruderale; C - Tagetes minuta; D - Acanthospermum australe; $\mathbf{E}$ - Acanthospermum hispidum; F - Tridax procumbens; G - Acritopappus confertus; $\mathbf{H}$-Acritopappus heterolepis; I - Acritopappus prunifolius; J - Acritopappus santosii; K-Ageratum conyzoides; L - Agrianthus empetrifolius; $\mathbf{M}$ - Bahianthus viscosus (A - L. Barres; B, L - V, Amorim; C, E, F, M - L. Moura; D, K - A. Gandara; G, J - M. Staudt; H - M. Alves; I - H. Ogasawara). 

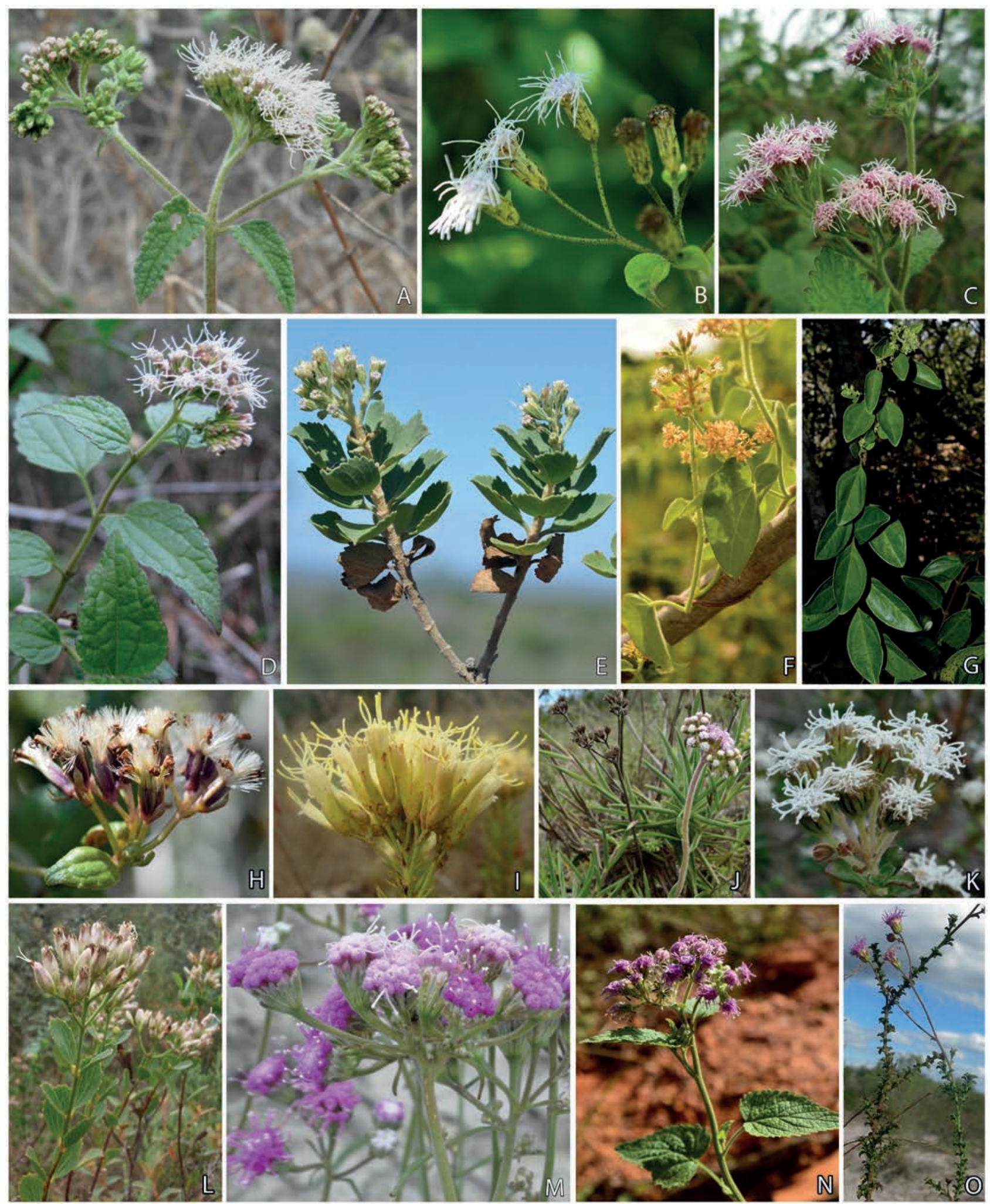

Figure 8. A - Bejaranoa semistriata; B - Chromolaena maximilianii; C - Conocliniopsis prasiifolia; D - Koanophyllon conglobatum; E - Lapidia apicifolia; F - Mikania congesta; G - Mikania elliptica; H - Mikania grazielae; I- Pseudobrickellia brasiliensis; J - Scherya bahiensis; K Stylotrichium edmundoi; L - Symphyopappus decussatus; $\mathbf{M}$ - Trichogonia campestris; $\mathbf{N}$ - Trichogonia salviifolia; $\mathbf{O}$ - Trichogonia tombadorensis (A, E, J, K - L. Barres; B, F, G, H, N - A. Gandara; C, D, L - V. Amorim; I - N. Roque; M, O - M. Staudt). 
Diversity and phytophysiognomies: specifics regarding Asteraceae

Studies on the flora of Morro do Chapéu reveal that the vegetation found in the northeastern region of the municipality is predominantly composed of arborealshrubby caatinga. Meanwhile, extensive areas of campos rupestres can be found in the central region, whereas semi-deciduous forests are located in the southwest and southeast. Associated with these phytophysiognomies, gallery forests and ecotonal vegetation exhibit complex areas of transition depending on topography and elevation (Silva 1995; França \& Melo 2013).

The distribution of Dasyphlyllum diamantinense, included in a basal tribe of Asteraceae, is restricted to the region of Chapada Diamantina (Saavedra et al. 2014), where it can be found in semi-deciduous forest throughout the study area. The other species of this genus that occur in the region $(D$. brasiliense and D. sprengelianum) can be found in carrasco and caatinga areas.

Considered an endemic of Bahia, Trixis pruskii occurs predominantly in gallery forest in sandy soils or between rocks. The other species of this genus that occur in the region (T. antimenorrhoea, T. calycina and T. vauthieri) are found in other phytophysiognomies, such as border parts of semi-deciduous seasonal forest, or ecotones between campo rupestre and caatinga vegetation.

Richterago is an endemic genus of Brazil, and although more than half of its species are restricted to Espinhaço Range (Roque \& Pirani 2014), only one species, Richterago discoidea, was found to occur in the study area. Moquiniastrum shows two of the six recognized species in the State of Bahia., M. blanchetianum and M. oligocephalum are found in transitional areas between campo rupestre and caatinga at elevations above $1000 \mathrm{~m}$ on sandy soils, but without rocky outcrops.

The genera Stilpnopappus and Vernonanthura, represented by four species each, and the genus Eremanthus, represented by two, were the predominant groups of Vernonieae in Morro do Chapéu, where they occurred in transitional areas.

The absence of species of Lychnophora, and the low number of species of Lessingianthus, reveal an unusual pattern compared to other areas in Espinhaço Range, since both genera have their greatest diversity in cerrado and campo rupestre phytophysiognomies (Giulietti et al. 1987; Hind 1995; Pirani et al. 2003; Zappi et al. 2003; Moura \& Roque 2014; Campos et al. 2016; Roque et al. 2016).

According to Fiaschi \& Pirani (2009), Lychnophora and Eremanthus are key elements for understanding the origin of the flora endemic to the cerrado. Therefore, the lack, or low representation, of, these genera may be associated with the difficulty in delimiting areas of cerrado sensu stricto in Morro do Chapéu.
The species Acritopappus confertus, Aspilia martii, Calea candolleana, Eremanthus capitatus, Lepidaploa aurea and Lepidaploa lilacina are widely distributed throughout different phytophysiognomies of Morro do Chapéu, such as campos rupestres, transition zones between campo rupestre and the caatinga, and the outermost parts of semi-deciduous seasonal forests.

On the other hand, Agrianthus empetrifolius, Cyrtocymura harleyi and Stilpnopappus tomentosus are found predominantly in campo rupestre vegetation where they are restricted to rocky outcrops. Scherya bahiensis, Stilpnopappus sp. nov. and Stylotrichium edmundoi are considered micro-endemics of a specific area of campos rupestres called the "Tabuleiro do Tigre" (Fig. 1D). Apart from these species, Acritopappus santosii, Lapidia apicifolia and Trichogonia tombadorensis are also identified as endemic to Morro do Chapéu. According to Conceição et al. (2005), this microendemism is particularly influential in campos rupestres where a significant part of the diversity is composed of less frequently occurring species.

Among the patterns of geographic distribution proposed for the flora of campos rupestres by Giulietti \& Pirani (1988), one specific pattern can be highlighted, that comprising species whose occurrence is restricted to Espinhaço Range. This pattern can be divided into two subgroups. The first group encompasses species whose occurrence is restricted to campos rupestres, but at the same time are widely distributed throughout the Espinhaço Range. The second group encompasses species that are endemic to one specific locality or to only a few regions of the Espinhaço Range located in the state of Minas Gerais, or in the Chapada Diamantina in the state of Bahia. Thus, the endemic species of Morro do Chapéu can be subsumed into the second subgroup. As pointed out by Conceição \& Pirani (2005), the contiguity between different habitat types produces a high degree of heterogeneity in floristic structure and composition in certain restricted areas, reflecting variation in substrates. This phenomenon, therefore, contributes to the high number of endemic species of campo rupestre.

According to Zappi (2008), the implementation of an environmental protection area and the development of management plans have to be regarded as extremely relevant in the case of Morro do Chapéu, where the unique enclaves of the caatinga and campo rupestre are endangered. In this sense, further studies on the taxonomy, ecology and biogeography of the representative and endemic groups found in the campos rupestres of Espinhaço Range is considered essential. These studies can provide crucial information regarding evolutionary patterns that have determined the origin of rare species, and thus can provide insight into conservation. Furthermore, they can provide important criteria for the development of strategies for biodiversity conservation (Kruckeberg \& Rabnowitz 1985; Rapini et al. 2008; Rapini et al. 2009). 
In this sense, it is important to emphasize that Morro do Chapéu possesses unique floristic diversity, and a significant number of species of Asteraceae possess restricted distributions and high degrees of endemism. We stress that this floristic diversity is constantly at high risk of becoming endangered due to population reductions and loss of habitat, particularly considering the intense activities involving sand-extraction and growing exploitation for agriculture.

\section{Key to the Asteraceae species from Morro do Chapéu, Bahia, Brazil}

1. Discoid (flowers with one corolla type: tubulose, bilabiate or ligulate) or disciform heads (flowers with two or three corolla types, always including corolla tubulose-filiform).

2. Stems with geminate axillary spines; lamina and involucral bracts with apex mucronate or spinescent.

3. Capitulescence cymose; involucre 2-3 × 1.5-2.2 cm; heads 20-60 flowers (Fig. 2B) ....... Dasyphyllum sprengelianum

3'. Capitulescence paniculiform or racemiform; involucre 1-1,5 × 0,5-1,1 cm; heads 10-15 flowers.

4. Spines larger or the same size as leaves; lamina with apex apiculate or aristate; involucre cylindrical

Dasyphyllum diamantinense

4'. Spines smaller than leaves or stems without spines; lamina with apex inermous or mucronate; involucre campanulate (Fig. 2A) Dasyphyllum brasiliense

2'. Stems without spines; lamina and involucral bracts not mucronate or spinescent at apex.

5. Heads with all flowers with corolla bilabiate.

6. Lamina concolorous; involucre uniseriate ..... Trixis pruskii

6'. Lamina discolorous; involucre 2-seriate.

7. Stems winged, viscid; involucral bracts with dense trichomes at the apex (Fig. 2E) Trixis vauthieri

7'. Stems cylindrical, not viscid; involucral bracts without tufts of trichomes at the apex.

8. Leaves sessile, persistent; capitulescence with flowering branches divaricate .................. Trixis antimenorrhoea

8'. Leaves petiolate, deciduous, pubescent scars on the stems; capitulescence without flowering branches divaricated (Fig. 2D) Trixis calycina

5'. Heads with flowers with corolla tubular, tubular-filiform or ligulate.

9. Plants with latex; all flowers with corolla ligulate (Fig. 3A) Sonchus oleraceus

9'. Plants without latex; flowers with corolla tubular, tubular-filiform and/or ligulate.

10. Leaves and involucral bracts with glandular and aromatic pockets (dark dots or lines).

11. Leaf blade linear or filiform (Fig. 7A).....

Porophyllum obscurum

11'. Leaf blade elliptic (Fig. 7B) Porophyllum ruderale

10'. Leaves and involucral bracts without glandular and aromatic pockets.

12. Heads unisexual (head pistillate uniflorous, flower without corolla; head staminate with several flowers and involucral bracts connate), plant monoecious .....

Ambrosia artemisiifolia

12'. Heads bisexual (flowers with corolla), if unisexual, plant dioecious or gynodioecious.

13. Involucral bracts hyaline, white or yellow.

14. Corolla purple or lilac; pappus of bristles connate at the base (Fig. 5A) Gamochaeta americana

14'. Corolla yellow or white-yellow; pappus of free bristles ....

13 . Involucral bracts opaque, green, brown or vinaceous.

15. Heads with trimorphic flowers (ray flowers with corolla ligulate, flowers intermediate with corolla filiform, and disc flower with corolla bilabiate) (Fig. 2C) Chaptalia integerrima

15'. Heads with flowers monomorphic or dimorphic.

16. Plants dioecious.

17. Heads forming a leafy raceme of glomerule; leaf blade linear Baccharis linearifolia

17'. Capitulescence corymbiform, paniculiform or panicle-corymbiform; leaf blade elliptic, spatulate, lanceolate, oblanceolate, obovoid or orbicular.

18. Leaves trinerved.

19. Stems and leaves cinereous-tomentose (Fig. 5B) Baccharis cinerea

19 '. Stems and leaves glabrous Baccharis trinervis 18. Leaves penninerved.

20. Leaf blade tomentose in the abaxial surface with white to cinereous trichomes and glabrescent in the adaxial surface, apex acute to acuminate ..... Baccharis calvescens 20'. Leaf blade glabrous, viscid, apex rounded or obtuse.

21. Heads solitaries in the axil of the stems Baccharis reticularia 
21'. Capitulescence in panicle-corymbiform.

22. Leaf blade spatulate to oblanceolate, margin dentate, base cuneate; heads in glomerule sessile or subsessile Baccharis retusa

22'. Leaf blade ovate or obdeltade, margin entire or denticlate, base atenuate; heads in glomerule pedicellate

Baccharis alleluia

16'. Plants monoecious or gynodioecious.

23. Leaves opposite.

24. Heads with 4 involucral bracts and 4 flowers, 5 involucral bracts and 5 flowers or 2 involucral bracts and 4 flowers.

25. Heads with 2 flowers pistillate and 2 flowers bisexual and 2 involucral bracts

. Synedrellopsis grisebachii

25 . Heads with all flowers bisexual and 4 or 5 involucral bracts.

26. Heads with 5 involucral bracts and 5 flowers.

27. Leaf blade coriaceous, glabrous, margin entire

Hoehnephytum almasense

27. Leaf blade membranaceous, adaxial face with glandular trichomes stipitate and abaxial face with sessile glandular trichomes, margin crenate Stevia morii

26 . Heads with 4 involucral bracts and 4 flowers.

28. Cypsela 10-costate (Fig. 8H) Mikania grazielae

28'. Cypsela 5-costate.

29. Leaf blade ovate, margin dentate.

30. Leaf blade with apex obtuse, base oblique to rounded; capitulescence thyrsoid

30'. Leaf blade with apex acute, base hastate; capitulescence glomeruliform Mikania phaeoclados

29'. Leaf blade elliptic or cordiform, margin entire or crenulate.

Mikania glomerata

31. Leaf blade elliptic, apex acuminate, margin entire, revolute, base attenuate (Fig. 8G) Mikania elliptica

31'. Leaf blade cordiform, apex acute, margin crenulate, sinuate, base cordate.

32. Hexagonal branches; capitulescence corymbiform

Mikania cordifolia

32'. Cylindrical branches; capitulescence glomeruliform (Fig. 8F)

Mikania congesta

24 '. Heads with 5 or more involucral bracts and 4 or more flowers.

33. Leaf blade with venation subparallel; involucral bracts and paleae with cartaceous and sinuous appendices at apex (Fig. 8J)

Scheryabahiensis

33'. Leaf blade with venation penninerved or acrodromous; involucral bracts and paleae without cartaceous and sinuous appendices at apex.

34. Receptacle paleaceous; pappus aristate, coroniform, coroniform-aristate or absent.

35. Pappus aristate ( 2 to 5 caducous awns) or absent.

36. Leaf blade lanceolate, conduplicate, apex caudate, margin serrate, base attenuate (Fig. 7G) ........ Acritopappus confertus

36'. Leaf blade elliptic to obovate, flat, apex obtuse to apiculate, margin serrulate, base rounded (Fig. 7I) Acritopappus prunifolius

35'. Pappus coroniform.

37. Heads with 20-26 flowers; $15-21$ paleae in the receptacle (Fig. 7H) ........ Acritopappus heterolepis

37. Heads with 5-8 flowers; 1-2 paleae in the receptacle.

38. Leaf blade deltoid to ovate (Fig. $7 \mathrm{~J}$ ) Acritopappus santosii

38'. Leaf blade elliptic Acritopappus sp. nov.

34'. Receptacle epaleaceous; pappus of bristle, bristle-barbelate or paleaceous-aristate.

39. Heads with 58-75 flowers; pappus with 5 awn-tipped scales (Fig. 7K) Ageratum conyzoides

39 '. Heads with 4 to 28 flowers; pappus of bristle or bristle-barbelate.

40. Involucre strongly imbricate with 30-36 involucral bracts, deciduous.

41. Leaf blade elliptic, apex acute, margin entire Chromolaena morii

41'. Leaf blade ovate, apex caudate, margin dentate (Fig. 8B) Chromolaena maximilianii 40'. Involucre imbricate with 7-20 involucral bracts, persistent.

42. Cypsela obconical with vesicular trichomes; pappus biseriate (Fig. 8L)

Symphyopappus decussatus 
42'. Cypsela cylindrical without vesicular trichomes; pappus uniseriate.

43. Shrub $0.5 \mathrm{~m}$ alt.; leaves arranged along the stem; leaf blade ovate, apex acuminate to caudate, base cordate (Fig. 8D) Koanophyllon conglobatum

43'. Shrub 3-4 m alt.; leaves congested at the apex of the stem; leaf blade orbicular to obovate, apex rounded to truncate, base cuneate to truncate (Fig. 8E)

\section{3'. Leaves alternate.} Lapidia apicifolia

44. Receptacle deeply alveolate involving the cypsela (Fig. 3B) Albertinia brasiliensis 44'. Receptacle alveolate, not involving the cypsela.

45. Connective appendage of the anther apiculate; style branches short and glabrous.

46. Plants monoecious, subshrubs; pappus uniseriate (Fig. 2F) Richterago discoidea 46. Plants gynodioecious, shrubs or trees; pappus 2-3-seriate.

47. Capitulescence smaller than leaves (Fig. $2 \mathrm{H}$ ) Moquiniastrum oligocephalum

47'. Capitulescence larger than leaves (Fig. 2G) Moquiniastrum blanchetianum

45'. Connective appendage of other formats; style branches long, with trichomes or papillate.

48. Leaf blade pinnatipartite Artemisia vulgaris

48'. Leaf blade entire or lyrate-pinnatifid at the base.

49. Heads with disc flowers with corolla tubular and bisexual or functionally staminate and flower at the margin with corolla tubular-filiform and pistillate.

50. Stems cylindrical; involucre calyculate Erechtites hieracifolius

50 '. Stems alate; involucre ecalyculate.

51. Leaf blade strongly discolorous; heads grouped in spike of glomerules

Pterocaulon alopecuroides

51'. Leaf blade concolorous or slightly discolorous; capitulescence of other types.

52. Leaf blade concolorous; disc flowers bisexual.

53. Plant with few ramification (up to 3 ) and branches with few heads; leaf blade with base lyratepinnatifid..... Conyza primulifolia

53'. Plant with many ramification (8 or more) and branches with many heads; leaf balde with base entire Conyza sumatrensis

52 '. Leaf blade slightly discolorous; disc flowers functionally staminate.

54. Pappus of bristles (Fig. 5D) .. Pluchea sagittalis

54'. Pappus absent Epaltes brasiliensis

49'. Head with all flowers with corolla tubular and bisexual.

55. Head with involucre uniseriate.

56. Subshrub or shrub; leaf blade lanate on the adaxial face and albo-tomentose on the abaxial face; flowers with corolla yellow .... Senecio macrotis

56'. Herb; leaf blade glabrous to sparsely pubescent on both faces; flowers with corolla red (Fig. 5E)

55'. Head with involucre bi to multiseriate.

57. Capitulescence double racemiform; style branches minutely bifid, distal portion swollen papillate below the bifurcation (Fig. 4I) ...... Moquinia racemosa 57'. Solitary heads or capitulescence umbelliform, corymbiform, glomeruliform, paniculiform or cymose-scorpioid; style branches long, cylindrical, papillate or pilose below bifurcation and apex obtuse or clavate, or pilose extending below the bifurcation and apex acute.

58. Style branches papillate or pilose below bifurcation, apex obtuse or clavate.

59. Receptacle paleaceous (1-2 pales); style branches pilose below the bifurcation.

60. Leaf sessile to subpetiolate (c. $0.2 \mathrm{~cm}$ long), leaf blade $0.8-1.5 \mathrm{~cm}$ long Stylotrichium corymbosum

60'. Leaf petiolate (1.3-1.5 cm long), leaf blade $0.4-0.5 \mathrm{~cm}$ long (Fig. $8 \mathrm{~K}$ ) Stylotrichium edmundoi

59'. Receptacle epaleaceous; style branches with papillae above the bifurcation.

61. Corolla lobes densely pubescent; cypsela stipitate.

62. Leaves fasciculate and congested; leaf blade obovate (Fig. 8O) Trichogonia tombadorensis 62'. Leaves lax; leaf blade narrow-elliptic, oblanceolate, lanceolate or triangular. 
Asteraceae of Morro do Chapéu, Bahia, Brazil:

richness, endemism and conservation

63. Leaf blade $0.8-1.7 \times 0.4-0.7 \mathrm{~cm}$, narrow-elliptic or oblanceolate, base attenuate (Fig. $8 \mathrm{M}) \ldots$

Trichogonia campestris

63'. Leaf blade $2.5-7 \times 1-3 \mathrm{~cm}$, lanceolate or triangular, base truncate (Fig. $8 \mathrm{~N}$ )

Trichogonia salviifolia

61'. Corolla lobes glabrous or with trichome glandular-punctate; cypsela cylindrical.

64. Leaf sessile, leaf blade linear, margin entire.

65. Involucral bracts 22, 2-4 seriate; receptacle convex or conical, paleaceous; flowers with corolla lilac to pink (Fig. 7L) .....

Agrianthus empetrifolius

65'. Involucral bracts 12-14, 5 seriate; receptacle flat, epaleaceous; flowers with corolla cream

(Fig. 8I) Pseudobrickellia brasiliensis

64'. Leaf petiolate, leaf blade obovate, ovate, lanceolate, elliptic, margin crenate, dentate or serrate in the upper $1 / 3$.

66. Plants viscid; leaf blade concolour, margin serreate in the upper 1/3; cypsela glabrous

(Fig. 7M) Bahianthus viscosus

66'. Plants not viscid; leaf blade discolorous, margin dentate or crenate; cypsela pilose or with glandular punctate or stipitate trichome.

67. Leaf blade with margin dentate and base oblique; corolla with papillae projections inside the lobes Prolobus nitidulus

67'. Leaf blade with margin crenate and base truncate; corolla glabrous inside the lobes.

68. Heads with 4-5 flowers, corolla white to pink; receptacle flat (Fig. 8A)

Bejaranoa semistriata

68'. Heads with 25-35 flowers, corolla lilac; receptacle conical (Fig. 8C) Conocliniopsis prasiifolia

58'. Style branches pilose below bifurcation, apex acute.

69. Scandent shrub; quadrangular stems; leaf blade of the abaxial face densely lepidote with translucent gland Piptocarpha leprosa 69'. Erect herb, subshrub, shrub or tree; terete stems; leaf blade without indumentum lepidote and translucent glands.

70. Plants with leaf-rosette, internode congested and involucre 2-seriate.

71. Leaf blade oblanceolate to obovate; bracts cordiform at the base of the head; pappus uniseriate Elephantopus mollis

71'. Leaf blade lanceolate; bracts narrow lanceolate at the base of the head; pappus biseriate .. Elephantopus hirtiflorus

70'. Plants not rosulate, internode spaced and involucre 3-8-seriate.

72. Head with 1-4 flowers; pappus 3-5-seriate.

73. Heads $2-5$ per glomerule; 3 flowers per head (Fig. $3 \mathrm{H}$ ) Eremanthus capitatus 73'. Heads 75-105 per glomerule; 1 flower per head (Fig. 3I) Eremanthus glomerulatus

72'. Heads with 5 or more flowers; pappus biseriate.

74. Heads pedunculate of second order in glomerule, retted with age.

75. Leaf sessile, with base auriculate (Fig. 4C)

75'. Leaf petiolate, base cuneate ..... Paralychnophora harleyi

Paralychnophora reflexoauriculata

74 '. Heads pedunculate or sessile in other types of capitulescence, erect.

76. Stems fistulous; leaf blade pinnaripartite, sheathing (Fig. 3E)

76'. Stems not fistulous; leaf blade entire, not amplexicaul.

77. Leafy bracts surrounding the head; receptacle alveolate-aristate.

78. Heads with ca. 150 flowers; apex of involucral bracts aristate (Fig. 3D)

Centratherum punctatum

78'. Heads with 24-60 flowers; apex of involucral bracts acute, acuminate or apiculate.

79. Leaf blade ovate to orbicular, margin dentate (Fig. 4E)

79'. Leaf blade elliptic, lanceolate, narrow-lanceolate or linear, margin entire. 
80. Subshrub with decumbent branches; leaf blade with base attenuate (Fig. 4D) ....... Stilpnopappus semirianus 80'. Subshrub with erect branches; leaf blade with base cuneate or semi-amplexicaul. 81. Leaf blade flat, apex acuminate, base cuneate Stilpnopappus suffruticosus

81'. Leaf blade conduplicate, apex acute, base semi-amplexicaul

Stilpnopappus tomentosus

77'. Heads without leafy bracts at the base; receptacle flat, fimbriate, alveolate without aristae.

82. Capitulescence glomeruliform; leaf blade with stellate and glandular-punctate trichomes on both faces (Fig. 3C) Blanchetia heterotricha 82'. Capitulescence paniculiform, raceme-corymbiform or cymose-scorpioid; leaf blade without stellate and glandular-punctate trichome

83. Shrub and tree; capitulescence in pyramidal panicle.

84. Branches and venation vinaceous; leaves sessile; leaf blade narrow-elliptic ......... Vernonanthura laxa

$84^{\prime}$. Branches and venation without vinaceous colour; leaves petiolate; leaf blade obovate or elliptic.

85. Involucral bracts 78-80; flowers ca. 41 (Fig. 4F)

Vernonanthura brasiliana

85'. Involucral bracts 22-62; flowers 11-27.

86. Involucre 5-seriate; flowers 11-13, corolla pink to white (Fig. 4H)

Vernonanthura subverticillata

86'. Involucre 7-9-seriate; flowers 25-27, corolla cream (Fig. 4G)

Vernonanthura polyanthes

83'. Subshrub to shrub; capitulescence in cymose-scorpioid.

87. Heads arranged in two series (subduplicate) in the flowering branches.

88. Leaf blade oblong to ovate, apex obtuse to rounded, margin crenulate to denticulate, base rounded, abaxial face lanate (Fig. $3 \mathrm{~F}$ )

Cyrtocymura harleyi

88'. Leaf blade lanceolate, apex acute, mucronate or acuminate, margin entire to denticulate, base attenuate, abaxial face pubescent to sericeous (Fig. 3G)

Cyrtocymura scorpioides

87'. Heads in the one series in the flowering branches.

89. Cypsela pubescent, without glandular-punctate

Lessingianthus morii

89'. Cypsela sericeous, tomentose or setose, glandular-punctate.

90. Plants with angulate branches.

91. Leaf blade with adaxial face strigose with glandular sessile trichomes and abaxial face albo-tomentose (Fig. 3M)

Lepidaploa cotoneaster

91'. Leaf blade puberulous with glandular sessile trichomes on both faces (Fig. $3 \mathrm{~K})$ Lepidaploa bahiana

90'. Plants with cylindrical branches.

92. Leaf blade closely linear, concolorous (Fig. 4B)

Lepidaploa tombadorensis

92'. Leaf blade ovate, deltoid, lanceolate, elliptic, discolorous.

93. Leaf blade ovate to deltoid; flowers 34-39 per head (Fig. 3J)

93'. Leaf blade elliptic to ovate; flowers 10-21 per head.

Lepidaploa aurea

94. Leaf blade 0.6-2.1 × 0.5-1.4 cm; cypsela densely sericeous (Fig. 3L)

Lepidaploa chalybaea

94'. Leaf blade 2.6-7.4 × 1.5-3.5 cm; cypsela tomentose (Fig. 4A) ..... Lepidaploa lilacina

1'. Radiate head (2 corolla types: liguliform at margin and tubulose in the disc). 


\section{Asteraceae of Morro do Chapéu, Bahia, Brazil: \\ richness, endemism and conservation}

95. Leaves alternate or upper alternate and lower opposite.

96. Leaves and involucral bracts with glandular and aromatic pockets (dark spots or lines); involucre uniseriate (Fig. 7C) Tagetes minuta

96'. Leaves and involucral bracts without glandular and aromatic pockets; involucre 2-4 seriate.

97. Receptacle epaleaceous; pappus coroniform inconspicuous (Fig. 5C) Egletes viscosa

97'. Receptacle paleaceous; pappus coroniform (c. $2 \mathrm{~mm}$ long.), aristate or paleaceous.

98. Floral peduncle fistulous; pappus coroniform.

99. Involucre 3-4-seriate, the inners with apex rounded or obtuse, corolla yellow (Fig. 6C) ..... Tithonia diversifolia

99'. Involucre biseriate, the inner with apex acuminate, corolla orange (Fig. 6D) Tithonia rotundifolia

98. Floral peduncle not fistulous; pappus aristate.

100. Ray flowers neutral; cypsela with confined embryo in the center and flat border around ... Simsia dombeyana 100'. Ray flowers pistillate; cypsela alate.

101. Leaf blade lobed, margin dentate; flowers with corolla white (Fig. 6F) Verbesina macrophylla

101'. Leaf blade entire, margin serrate at $2 / 3$ upper; flowers with corolla yellow (Fig. 6E) ..... Verbesina glabrata 95'. All leaves opposite.

102. Pappus absent or insconspicuous (c. $0.1 \mathrm{~mm}$ long.).

103. Receptacle conical.

104. Involucre subglobose, 2-seriate with $9-11$ involucral bracts Acmella ciliata

104'. Involucre campanulate, uniseriate with 5-6 involucral bracts (Fig. 5H) Acmella uliginosa

103'. Receptacle flat or convex.

105. Cypsela with uncinate prickles.

106. Leaf blade rhombic-ovate; cypsela subcylindrical with uncinate prickles of the same size (Fig. 7D) .....

Acanthospermum australe

106'. Leaf blade obtrullate-obovate; cypsela obpyramidal compressed with uncinate prickles of the same size and two larger rigid awns at apex (Fig. 7E) Acanthospermum hispidum

105'. Cypsela without uncinated prickles.

107. Head with 2 flowers and 3 involucral bracts (Fig. 5L) Delilia biflora

107'. Head with 15 or more flowers and more than 5 involucral bracts.

108. Head sessile; cypsela striate (Fig. 5F) Enydra radicans

108'. Head pedunculate; cypsela smooth or tuberculate.

109. Peduncle fistulous; involucral bracts 5-6-seriate, apex rounded with dark blue or blackish line (Fig. 6H) Zinnia elegans

109'. Peduncle not fistulous; involucral bracts 2-seriate, apex acute or acuminate without dark blue or blackish line. 110. Flowers 78-110; cypsela oblanceoloid or obovoid (bacaceous aspect), smooth (Fig. 6B) ... Tilesia baccata

110'. Flowers c. 15; cypsela triquetrous or obpyramidal, tuberculate

Baltimora geminata

102'. Pappus coroniform, coroniform-aristate, aristate, scale, plumose or bristle.

111. Leaf blade pinnatisect; cypsela fusiform (Fig. 6I) Bidens pilosa

111'. Leaf blade entire; cypsela obconical, obpyramidal, obovoid or oblanceoloid.

112. Ray corolla linear; receptacle with paleae filiform (Fig. 5M) Eclipta prostrata

112'. Ray corolla elliptic or narrow elliptic; receptacle with paleae linear, lanceolate, ovate or narrowly- lanceolate.

113. Pappus plumose or bristle.

114. Prostrate herb; ray flowers white; pappus plumose and persistent (Fig. 7F) Tridax procumbens

114'. Erect herb; ray flowers yellow; pappus of bristle and deciduous (Fig. 6A) ..... Melanthera latifolia

113'. Pappus coroniform, coroniform-aristate, aristate or paleaceous.

115. Involucral bracts striate.

116. Corolla white; receptacle flat; pappus aristate (Fig. 5K) ............................................... Blainvillea acmella

116'. Corolla yellow; receptacle conical; pappus of scales (Fig. 5G) . Calea candolleana

115'. Involucral bracts no striate.

117. Ray flowers neutral; cypsela with basal scar.

118. Leaves sessile, chartaceous, leaf blade linear or lanceolate (Fig. 5I)

Aspilia martii

118'. Leaves short-petiolate (petiole up to $0.2 \mathrm{~cm}$ long), coriaceous, leaf blade narrowly-elliptic or elliptic (Fig. 5J)

117'. Ray flowers pistillate; cypsela without basal scar (Fig. 6G) Aspilia subalpestris Wedelia goyazensis 


\section{Acknowledgements}

The authors are grateful to Ir. Delmar Alvim for providing support during field works and Lidia Campos for the map. We also thank CNPq Brazil for the Master's scholarship granted to the first author, including a fellowship grants to NR (NR-3051139/2016-9) and Fapesb for the PhD scholarship for the second author (BOL0565/2015).

\section{References}

Alves M, Roque N. 2016. Flora da Bahia: Asteraceae - Tribo Heliantheae. Sitientibus, Série Ciências Biológicas 16: 1-63.

Barbosa MA. 1995. Clima. In: Rocha AJD, Costa IVG. (orgs.) Projeto mapas municipais: município de Morro do Chapéu (BA). Morro do Chapéu, Ministério de Minas e Energia. p. 39-52.

BFG - Brazil Flora Group. 2015. Growing knowledge: an overview of Seed Plant diversity in Brazil. Rodriguésia 66: 1085-1113.

Bremer K. 1994. Asteraceae: cladistics and classification. Portland,Timber Press.

Campos L, Guedes MLS, Acevedo-Rodrigues P, Roque N. 2016. Contributions to the floristic and vegetation knowledge of Espinhaço Septentrional, Bahia, Brazil. Brazilian Journal of Botany 40: 427-437.

Conceição AA, Pirani JR. 2005. Delimitação de habitats em campos rupestres na Chapada Diamantina: substratos, composição florística e aspectos estruturais. Boletim de Botânica da Universidade de São Paulo 23: 85-111.

Conceição AA, Rapini A, Pirani JR, et al. 2005. Campos rupestres. In: Juncá FA, Funch L, Rocha W. (eds.) Biodiversidade e Conservação da Chapada Diamantina. Brasília, Ministério do Meio Ambiente. p. 153-180.

Fiaschi P, Pirani JR. 2009. Review of plant biogeographic studies in Brazil. Journal of Systematics and Evolution 47: 477-496.

França F, Melo E. 2013. A complexidade da vegetação. In: França F, Melo E, Souza I, Pugliesi L. (org.) Flora de Morro do Chapéu. Vol. 1. Feira de Santana, Empresa Gráfica da Bahia. p. 17-19.

Funk VA, Susanna A, Stuessy TF, Robinson H. 2009. Classification of Compositae. In: Funk VA, Susanna A, Stuessy TF, Bayer RJ. (eds.) Systematics, Evolution and Biogeography of the Compositae. Vienna, IAPT. p. 171-189.

Giulietti AM, Menezes NL, Pirani JR, Meguro M, Wanderley MGL. 1987. Flora da Serra do Cipó, Minas Gerais: caracterização e lista das espécies. Boletim de Botânica da Universidade de São Paulo 9: 1-151.

Giulietti AM, Pirani JR. 1988. Patterns of geographic distribution of some plant species from the Espinhaço Range, Minas Gerais and Bahia, Brazil. In: Vanzolini PE, Heyer WR. (eds.) Proceedings of a workshop on Neotropical distribution patterns. Rio de Janeiro, Academia Brasileira de Ciências. p. 39-69.

Grandi TSM, Siqueira JC, Paula JA. 1988. Levantamento florístico da flora fanerogâmica dos campos rupestres da Serra da Piedade, Caeté, Minas Gerais. Pesquisas série Botânica 39: 89-104.

Guedes MLS, Orge MDR. 1998. Checklist das espécies vasculares do Morro do Pai Inácio (Palmeiras) e Serra da Chapadinha (Lençóis), Chapada Diamantina, Bahia, Brasil. Salvador, Instituto de Biologia - UFBA.

Harley RM. 1995. Introdução. In: Stannard BL. (ed.). Flora of the Pico das Almas - Chapada Diamantina, Bahia, Brazil. Kew, Royal Botanic Gardens. p. 43-78.

Harley RM, Simmons NA. 1986. Florula de Mucugê, Chapada Diamantina, Bahia, Brazil. Kew, Royal Botanic Gardens.

Hatschbach G, Guarçoni EAE, Sartori MA, Ribas OS. 2006. Aspectos fisionômicos da vegetação da Serra do Cabral - Minas Gerais - Brasil. Boletim do Museu Botânico Municipal 67: 1-33.

Hind DJN. 1995. Compositae. In: Stannard BL. (ed.) Flora do Pico das Almas - Chapada Diamantina, Bahia, Brasil. Kew, Royal Botanic Gardens. p. 175-278.
Hind DJN. 2003. Flora of Grão-Mogol, Minas Gerais: Compositae (Asteraceae). Boletim de Botânica da Universidade de São Paulo 21: 179-234.

Hind DJN, Miranda EB. 2008. Lista preliminar da Família Compositae na Região Nordeste do Brasil. Kew, Royal Botanic Gardens. p. 8-16.

IBGE - Instituto Brasileiro de Geografia e Estatística. 2012. Manual técnico da vegetação brasileira. Vol 2. Rio de Janeiro, IBGE.

Kruckeberg AR, Rabinowitz D. 1985. Biological aspects of endemism in higher plants. Annual Review of Ecology, Evolution, and Systematics 16: 447-479.

Martinelli G, Moraes MA. 2013. Livro Vermelho da Flora Brasileira. Rio de Janeiro, Andrea Jakobson Estúdio, Instituto de Pesquisas Jardim Botânico do Rio de Janeiro.

Maury CM. 2002. Avaliação e identificação de áreas e ações prioritárias para conservação, utilização sustentável e repartição de benefícios da biodiversidade brasileira. Brasília, Ministério do Meio Ambiente.

Moura L, Roque N. 2014. Asteraceae no município de Jacobina, Chapada Diamantina, Estado da Bahia, Brasil. Hoehnea 41: 573-587.

Panero JL, Funk VA. 2008. The value of sampling anomalous taxa in phylogenetic studies: major clades of the Asteraceae revealed. Molecular Phylogenetics and Evoluiton 47: 757-782.

Panero JL, Freire SE, Espinar LA, Crozier BS, Barboza GE, Cantero JJ. 2014. Resolution of deep nodes yields an improved backbone phylogeny and a new basal lineage to study early evolution of Asteraceae. Molecular Phylogenetics and Evolution 80: 41-53.

Peixoto AL, Maia LC. 2013. Manual de Procedimentos para Herbários. Recife, Ed. Universitária da UFPE.

Pirani JR, Giulietti AM, Mello-Silva R, Meguro M. 1994. Checklist and patterns of geographic distribution of the vegetation of Serra do Ambrósio, Minas Gerais, Brazil. Revista Brasileira de Botânica 17: 133-147.

Pirani JR, Mello-Silva R, Giulietti AM. 2003. Flora de Grão-Mongol, Minas Gerais, Brasil. Boletim de Botânica da Universidade de São Paulo 21:1-24.

Queiroz LP, França F, Giulietti AM et al. 2005. Caatinga. In: Juncá FA, Funch LS, Rocha W (eds.). Biodiversidade e conservação da Chapada Diamantina. Ministério do Meio Ambiente, Brasília. p. 96-120.

Rapini A, Ribeiro PL, Lambert S, Pirani JR. 2008. A flora dos campos rupestres da Cadeia do Espinhaço. Megadiversidade 4: 15-23.

Rapini A, Andrade MJG, Giullietti AM, Queiroz LP, Silva JMC. 2009. Introdução. In: Giulietti AM, Rapini A, Andrade MJG, Queiroz LP, Silva JMC. (eds.) Plantas raras do Brasil. Belo Horizonte, Conservação Internacional do Brasil. p. 23-35.

Rizzini CT. 1997. Tratado de Fitogeografia do Brasil. 2nd. edn. Rio de Janeiro, Âmbito Cultural Edições Ltda.

Rocha AJD, Costa IVG. 1995. Projeto Mapas Municipais - Município de Morro do Chapéu (BA): informações básicas para o planejamento e administração do meio físico. Salvador, Ministério de Minas e Energia Companhia de Pesquisa de recursos Minerais, Prefeitura de Morro do Chapéu-BA.

Rocha AJD, Pedreira AJ. 2009. Projetos Geoparques - Geoparque Morro do Chapéu, BA. Salvador, Ministério de Minas e Energia - Secretaria de Geologia e Transformação Mineral. Serviço Geológico do Brasil - CPRM.

Rocha WJSF, Juncá FA, Chaves JM, Funch L. 2005. Considerações finais e recomendações para conservação. In: Juncá FA, Funch LS, Rocha W. (eds.) Biodiversidade e conservação da Chapada Diamantina. Brasília, Ministério do Meio Ambiente. p. 409-435.

Roque N, Bautista HP. 2008. Asteraceae: caracterização e morfologia floral. Salvador, EDUFBA.

Roque N, Pirani JR. 2014. Taxonomic Revision of Richterago (Asteraceae, Gochnatieae). Systematic Botany 39: 997-1026.

Roque N, Oliveira EC, Moura L, et al. 2016. Asteraceae no Município de Mucugê, Chapada Diamantina, Bahia, Brasil. Rodriguésia 67: 125-202.

Saavedra MM, Monge M, Guimarães EF. 2014. Dasyphyllum diamantinense (Asteraceae, Barnadesioideae): a new species from the Chapada Diamantina, Bahia State, Brazil. Phytotaxa 174: 231-236. 
Asteraceae of Morro do Chapéu, Bahia, Brazil:

richness, endemism and conservation

Silva SB. 1995. Vegetação. In: Rocha AJ.D, Costa IVG. (orgs.) Projeto mapas municipais: município de Morro do Chapéu (BA). Morro do Chapéu, Ministério de Minas e Energia. 113-121.

Silveira FAO, Negreiros D, Barbosa NPU, et al. 2015. Ecology and evolution of plant diversity in the endangered campo rupestre: a neglected conservation priority. Plant and Soil 403: 129-152.

Thiers B. 2017 [continuously updated]. Index Herbariorum: A global directory of public herbaria and associated staff. New York Botanical Gardens Virtual Herbarium. http://sweetgum.nybg.org/ih/. 10 de Apr. 2017.

Zappi DC. 2008. Fitofisionomia da Caatinga associada à Cadeia do Espinhaço. Megadiversidade 4: 33-37.

Zappi DC, Lucas E, Stannard BL, et al. 2003. Lista das plantas vasculares de Catolés, Chapada Diamantina, Bahia, Brasil. Boletim de Botânica da Universidade de São Paulo 21: 251-400. 